\title{
The effect of Selenium on thyroid physiology and pathology
}

Elżbieta Skowrońska-Jóźwiak, $\underline{\text { Aff1 }}$

Corresponding Affiliation: Aff1

\begin{tabular}{|l|l||l||l||}
\hline \hline \multicolumn{2}{|l||}{ ArticleInfo } \\
\hline \hline ArticleID & $:$ & 211 \\
\hline \hline ArticleDOI & $:$ & $10.1186 / 1756-6614-8-S 1-A 23$ \\
\hline \hline ArticleCitationID & $:$ & A23 \\
\hline \hline ArticleSequenceNumber & $:$ & 23 \\
\hline \hline ArticleCategory & $:$ & Meeting abstract \\
\hline \hline ArticleFirstPage & $:$ & 1 \\
\hline \hline ArticleLastPage & $:$ & 3 \\
\hline \hline ArticleHistory & $:$ & $\begin{array}{l}\text { RegistrationDate } \\
\text { OnlineDate }\end{array}$ \\
\hline \hline & & $\begin{array}{l}\text { Skowronska-Jóźwiak; licensee BioMed Central Ltd.2015 } \\
\text { This article is published under license to BioMed Central } \\
\text { Ltd. This is an Open Access article distributed under the } \\
\text { terms of the Creative Commons Attribution License } \\
\text { http://creativecommons.org/licenses/by/4.0), which permits } \\
\text { unrestricted use, distribution, and reproduction in any } \\
\text { medium, provided the original work is properly cited. The } \\
\text { Creative Commons Public Domain Dedication waiver } \\
\text { http://creativecommons.org/publicdomain/zero/1.0/) applies } \\
\text { to the data made available in this article, unless otherwise } \\
\text { stated. }\end{array}$ \\
\hline ArticleCopyright & \\
\hline
\end{tabular}

Aff1

Department of Endocrinology and Metabolic Diseases, Polish Mother's Memorial Hospital - Research Institute, Medical University of Lodz, Lodz, Poland

Spring School of Thyroidology organized by the Polish Thyroid Association 2014: abstracts of invited lectures

Spring School of Thyroidology organized by the Polish Thyroid Association 2014

Miedzyzdroje, Poland

23-24 May 2014

Publication of this supplement was funded by the Polish Thyroid Association. The Supplement Editors declare that they have no competing interests.

Meeting abstracts

Andrzej Lewinski

Mariusz Stasiolek 
Selenium (Se) is an important trace element for human physiology. It has anti-inflammatory, anti-neoplastic and anti-aging properties and protects from oxidative stress [1]. It is present in muscles, liver and kidneys, but reaches its highest concentration in the thyroid gland [2]. Selenium is incorporated in the molecular structure of a class of proteins called selenoproteins and the following well-characterized selenoproteins are found in the thyroid gland: glutathione peroxidases and thioredoxin reductases, protecting thyroid against free radicals, and deiodinases type I and II, participating in the synthesis of thyroid hormones [2]. Selenium status appears to have an impact on the development of several thyroid pathologies; autoimmune thyroid diseases, including Hashimoto disease and Graves-Basedow disease, thyroid orbitopathy, goiter, nodules and thyroid cancer.

Low concentrations of Se were shown in patients with Graves' disease [3] . Higher serum Se levels were seen in patients who went into remission and remained euthyroid during a 2-year follow-up period when compared with patients who did not receive permanent euthyreosis [4]. Results of these studies encourage the implementation of supplemental Se in the treatment of hyperthyroidism together with antithyroid drugs as well as to continue further research into new selenium-rich thyrostatics. The clinical study GRASS comparing the effectiveness of thyrotoxicosis treatment with thyrostatics alone and that accompanied by Se is just being carried out [ $[5]$. There are some data about the role of Se in the treatment of thyroid orbitopathy. Serum Se levels are lower in patients with orbitopathy when compared with Graves' disease patients without orbitopathy [6]. Selenium supplementation has proven to prevent deterioration of mild Graves' ophthalmopathy [7]. In the single study Se was shown to be effective in the prevention of the post-partum surge of TPO-Ab and thyroid dysfunction [ $\underline{8}$ ], however the data about Se effect in Hashimoto disease are conflicting; according to the Summary of a Cochrane Systematic Review the evidence to support or refute the efficacy of Se supplementation in people with Hashimoto's thyroiditis is incomplete and not reliable to help in clinical decision making [9]].

The influence of Se on goitrogenesis and carcinogenesis in the thyroid gland is still unclear. The data on effect of low Se levels in patients with goiter and thyroid nodules are divergent $[\underline{1}, \underline{10}]$. In vitro study showed that Se is able to decrease thyroid cancer growth [11]. In one study Se was inversely correlated with stages of thyroid cancer [12], but in a post-diagnosis study there was no association between fingernail selenium levels and thyroid cancer risk [13]

Conclusive results about the undisputable role of $\mathrm{Se}$ in the treatment of thyroid related diseases, including hyperthyroidism or thyroid orbitopathy, on a wider scale are still unavailable and further research is both required and recommended.

References

1. Rayman MP: Selenium and human health. Lancet 2012,379(9822):1256-1268. 10.1016/S0140-6736(11)61452-9

2. Schomburg L: Selenium, selenoproteins and the thyroid gland. Nat Rev Endocrinology 2011,8(3):160-171. 10.1038/nrendo.2011.174

3. Bülow Pedersen I, Knudsen N, Carlé A, Schomburg L, Köhrle J, Jørgensen T, et al.: Serum selenium is low in newly diagnosed Graves' disease: a population-based study. Clin Endocrinol (Oxf) 2013,79(4):584-590. 10.1111/cen. 12185

4. Wertenbruch T, Willenberg HS, Sagert C, Nguyen TB, Bahlo M, Feldkamp J, et al.: Serum selenium levels in patients with remission and relapse of Graves' disease. Med Chem 2007,3(3):281-284. $10.2174 / 157340607780620662$

5. Watt T, Cramon P, Bjorner JB, Bonnema SJ, Feldt-Rasmussen U, Gluud C, et al.: Selenium supplementation for patients with Graves' hyperthyroidism (the GRASS trial): study protocol for a randomized controlled trial. Trials 2013, 14: 119. 10.1186/1745-6215-14-119

6. Khong JJ, Goldstein RF, Sanders KM, Schneider H, Pope J, Burdon KP, et al.: Serum selenium status in Graves' disease with and without orbitopathy: a case-control study. Clin Endocrinol (Oxf) 
7. Marcocci C, Kahaly GJ, Krassas GE, Bartalena L, Prummel M, Stahl M, et al.: Selenium and the course of mild Graves' orbitopathy. New England Journal of Medicine 2011,364(20):1920-1931. 10.1056/NEJMoa1012985

8. Negro R, Greco G, Mangieri T, Pezzarossa A, Dazzi D, Hassan H: The influence of selenium supplementation on postpartum thyroid status in pregnant women with thyroid peroxidase autoantibodies. Journal of Clinical Endocrinology and Metabolism 2007,92(4):1263-1268. 10.1210/jc.2006-1821

9. van Zuuren EJ, Albusta AY, Fedorowicz Z, Carter B, Pijl H: Selenium Supplementation for Hashimoto's Thyroiditis: Summary of a Cochrane Systematic Review. Eur Thyroid J 2014,3(1):25-31.

10. Liu Y, Huang H, Zeng J, Sun C: Thyroid volume, goiter prevalence, and selenium levels in an iodine-sufficient area: a cross-sectional study. BMC Public Health 2013, 13: 1153. 10.1186/1471-2458-13-1153

11. Kato MA, Finley DJ, Lubitz CC, Zhu B, Moo TA, Loeven MR, et al.: Selenium decreases thyroid cancer cell growth by increasing expression of GADD153 and GADD34. Nutr Cancer 2010,62(1):66-73.

12. Jonklaas J, Danielsen M, Wang H: A pilot study of serum selenium, vitamin D, and thyrotropin concentrations in patients with thyroid cancer. Thyroid 2013,23(9):1079-1086. 10.1089/thy.2012.0548

13. Ren Y, Kitahara CM, Berrington de Gonzalez A, Clero E, Brindel P, Maillard S, et al.: Lack of association between fingernail selenium and thyroid cancer risk: a case-control study in French Polynesia. Asian Pac $J$ Cancer Prev 2014,15(13):5187-5194. 10.7314/APJCP.2014.15.13.5187 